\title{
МОТИВАЦЙНИЙ АСПЕКТ ВИКОРИСТАННЯ МЕДІАТЕКСТУ ПІД ЧАС НАВЧАННЯ АНГЛІЙСЬКОЇ МОВИ МАЙБУТНІХ ФАХІВЦІВ ІЗ ПОЧАТКОВОЇ ОСВІТИ
}

\author{
Лобачова I. М. \\ кандидат філологічних наук, доцент, \\ дочент кафедри теорії і практики початкової освіти \\ Донбаський державний педагогічний університет \\ вул. Генерала Батюка, 19, Слов'янськ, Донещька область, Украӥна \\ orcid.org/0000-0001-7102-1915 \\ sbitneva.irina@ukr.net
}

\begin{abstract}
Ключові слова: іншомовний медіатекст, комунікативна компетентність, лінгвометодичний аспект, міжкультурна комунікаџія, мовна картина світу, мотивація, ичифрове освітне середовище.
\end{abstract}

Статтю присвячено дослідженню мотиваційного аспекту використання медіатексту під час навчання англійської мови майбутніх фахівців із початкової освіти. 3'ясовано функціонування поняття «медіатекст» у науково-методичній літературі. Визначено домінантні ознаки медіатексту як навчального ресурсу. Окреслено практичну лінгвометодичну цінність медіатексту під час навчання іноземної мови. Особливу увагу звернено на те, що в інформаційному суспільстві XXI ст. медіатексти є найбільш поширеною формою існування сучасної мови. Робота 3 медіатекстами дає можливість говорити про формування медіаграмотності особистості, що володіє культурою спілкування з медіа, творчими, комунікативними здібностями, критичним мисленням, уміннями повноцінного сприйняття, інтерпретації та аналізу таких ресурсів. Окрім того, відзначено поширеність, доступність, практичність і велику кількість різножанрових медіатекстів у сучасному цифровому освітньому середовищі. Акцент зроблено і на тематичне розмаїття медіатекстів, безліч матеріалів, присвячених актуальним подіям сьогодення: економіці, політиці, науці й освіті, культурі та спорту, що становить інтерес для студентів і мотивує їх до іншомовної комунікації для обговорення запропонованих тем. Визначено, що іншомовний медіатекст - це джерело широкого кола національно-культурних мовних одиниць, що становлять особливу цінність для вивчення іноземної мови в контексті міжкультурної взаємодії: фразеологізмів, прислів'їв, національно-культурних стереотипів, ідіом, стилістичних фігур; звернення до прецедентних феноменів як одиниць когнітивної бази, що також сприяє взаєморозумінню під час міжкультурної комунікації. Медіатекст є важливим засобом для вирішення широкого спектру комунікативних і власне мовних методичних завдань. Використання медіатекстів під час навчання іноземної мови майбутніх фахівців із початкової освіти у виші сприяє заохоченню студентів до вивчення мови, бо такий медіаресурс являє собою цікавий («живий») мовний матеріал і привносять мотиваційний аспект в освітній процес, що відбувається через сприймання медіатексту як джерела лінгвістичного i навчального матеріалу. 


\title{
MOTIVATIONAL ASPECT OF USING THE MEDIA TEXT IN TEACHING ENGLISH TO FUTURE PRIMARY EDUCATION PROFESSIONALS
}

\author{
Lobachova I. M. \\ Candidate of Philological Sciences, Associate Professor, \\ Associate Professor at the Primary Education Theory and Practice Department \\ Donbas State Pedagogical University \\ Henerala Batiuka str., 19, Sloviansk, Donetsk region, Ukraine \\ orcid.org/0000-0001-7102-1915 \\ sbitneva.irina@ukr.net
}

Key words: foreign language media text, communicative competence, linguistic and methodological aspect, intercultural communication, linguistic picture of the world, motivation, digital educational environment.

\begin{abstract}
The article is devoted to the study of the motivational aspect of using a media text in teaching English to future primary education professionals. The functioning of the concept of "media text" in the scientific and methodological literature is clarified. The dominant features of the media text as a learning resource are identified. The practical linguistic and methodological value of the media text during foreign language teaching are outlined. Much attention is given to the fact that in the information society of the XXI century media texts are the most common form of existence of modern language. Working with media texts provides an opportunity to talk about the formation of media literacy of a person mastering a culture of communication with the media, creative, communication abilities, critical thinking, skills of full perception, interpretation and analysis of such resources. In addition, the prevalence, accessibility, practicality and a large number of different media texts in today's digital educational environment are noted. Emphasis is placed on the thematic diversity of media texts: many materials on current events: economics, politics, science and education, culture and sports, which are interested to students and motivate them to foreign language communication for discussing the proposed topics. It is determined that a foreign language media text is a source of a wide range of national and cultural language units that are of special value for learning a foreign language in the context of intercultural interaction: phraseology, proverbs, national and cultural stereotypes, idioms, stylistic figures; appeal to precedent phenomena as units of the cognitive base, which also promote mutual understanding during intercultural communication. A media text is an important tool for solving a wide range of communicative and linguistic methodological tasks. The use of media texts in teaching a foreign language to future primary education professionals in higher education institutions encourages students to learn the language, because this media resource is interesting language material and brings a motivational aspect to the educational process through the perception of a media text as a source of linguistic and educational material.
\end{abstract}

Постановка проблеми. Одним 3 основних тверджень сучасної методики навчання іноземної мови є думка про те, що процес навчання мови не $\epsilon$ ефективним без пізнання культури країни, мова якої вивчається, а також принципів міжкультурної комунікації. Беручи до уваги практичний досвід, навіть володіння мовою на високому рівні не може запобігти невдалому спілкуванню через непорозуміння між учасниками міжкультурного діалогу, якщо вони не знаються на культурних цінностях країн одне одного і можливостях вияву цих особливостей через вербальні та невербальні засоби спілкування та загальних принципах організа- ції міжкультурного діалогу. Так, одним із засобів успішного формування іншомовної комунікативної компетентності учасників є використання автентичних текстів - медіатекстів - під час навчання англійської мови: статей 3 іноземних журналів i газет, репортажів, радіо і телевізійних випусків новин, передач інших форматів, статей інформаційних сайтів [5, с. 94]. Такий медіаконтент має велике значення як навчальний автентичний ресурс під час навчання іноземної мови, бо такі тексти масової комунікації $\epsilon$ продуктом представників конкретного мовного суспільства, а отже, відображають його культуру і цінності. Окрім того, вони 
сприяють забезпеченню формування i розвитку міжкультурної та комунікативної компетентностей особистості, зокрема майбутнього педагога, який має бути спроможним використовувати іншомовну компетентність у подальшій професійній діяльності для забезпечення кар'єрного зростання.

Аналіз досліджень і публікацій. Дослідження проблеми функціонування медіатекстів у навчальному середовищі зацікавило багатьох учених: лінгвістів, педагогів, методистів, психологів, культурологів та ін. Термін «медіатекст» 3'явився в англомовній літературі у 90-х роках XX ст. і докладно розглядався у роботах таких зарубіжних авторів, як А. Белл, Т. ван Дейк, М. Монтгомері, Р. Фаулер, Т. Фахі та ін. У сфері лінгвістичних досліджень тексти масової інформації привертають увагу як матеріал для опису стану мови на конкретному часовому етапі, бо саме в них моментально відображаються і фіксуються зміни мовної дійсності, а отже, відбувається становлення мовної норми (Т. Добросклонська, Н. Сльнікова, В. Різун, І. Рогозіна, А. Мамалига, О. Пономарів та ін.). У лінгвометодичних розвідках акцент зроблено на практичну значущість використання медіатекстів у навчанні іноземної мови як зразків автентичного іншомовного матеріалу (І. Гуріненко, В. Мацько, Є. Міллер, Г. Оникович, Н. Саєнко, В. Усата, Ю. Усов та ін.).

Мета статті - дослідити мотиваційний аспект використання медіатексту під час навчання англійської мови майбутніх фахівців із початкової освіти. Для реалізації поставленої мети слід розв'язати такі завдання: 1) з'ясувати функціонування поняття «медіатекст» у науково-методичній літературі; 2) визначити домінантні ознаки медіатексту як навчального ресурсу; 3) окреслити практичну лінгвометодичну цінність медіатексту під час навчання іноземної мови.

Виклад основного матеріалу. В інформаційному суспільстві XXI ст. тексти масової інформаціï, або медіатексти, є найбільш поширеною формою існування сучасної мови. У традиційному розумінні текст - «писемний або усний мовленнєвий масив, що становить лінійну послідовність висловлень, об'єднаних у ближчій перспективі смисловими i формально-граматичними зв'язками, а в загальнокомпозиційному та дистантному плані - спільною тематикою і сюжетною заданістю» [6]. Стосовно друкованого або усного тексту йдеться про послідовність вербальних знаків, але медіатекст виходить за межі вербального рівня, бо включає у себе не лише вербальні знаки. До складу медіатексту входять неоднорідні знаки. У лінгвометодиці такі тексти називають полікодовими [4]. Більшість дослідників уважає, що текст, який функціонує у сфері масової кому- нікації, набуває, крім словесної оболонки, нові характеристики, зумовлені медійними властивостями того чи іншого засобу масової інформації, за допомогою якого цей текст передається аудиторії. Усі складники медіатексту функціонують одночасно як єдине ціле, як складний організм. Медіатекст визначається багатьма сучасними науковцями як сукупність вербальних і медійних ознак, що мають специфічні риси вияву мовних полікодів, у яких відображено мовну картину світу певного суспільства, що стає оригінальним об'єктом для діяльності в освітньому середовищі [1], і зокрема в методологічних дослідженнях, для визначення практичної значущості медіатекстів у навчанні іноземної мови.

Питання про медіатекст як навчальний ресурс можна вважати особливо актуальним для сучасної методики викладання іноземних мов. Такий навчальний текст має відповідати низці вимог, що стосуються його автентичності, актуальності змісту, обсягу, рівню складності тощо. Так, у пошуках автентичного англійського тексту, що відповідає подібним вимогам, звертаються до медіатекстів, насамперед до друкованих газетних і журнальних текстів різних жанрів, бо ці тексти мають певні лінгвометодичні переваги, які дають змогу застосовувати їх як автентичні навчальні засоби, призначені для роботи зі студентами будьяких спеціальностей і тими, хто має намір використовувати іноземну мову в подальшій професійній діяльності. Також варто звернути увагу і на телевізійні медіатексти, що є динамічним відображенням картини світу англомовного суспільства i базовими для масової інформації: у них комплексно представлено всі головні риси й особливості певної сфери вживання мовлення.

Зазначимо, що не слід забувати про лінгвометодичну цінність художніх текстів, зокрема відомих зразків зарубіжної класичної літератури, що також стимулюють зацікавленість студентів до вивчення англійської мови. Водночас підкреслимо, що художні тексти далеко не завжди є придатними для роботи зі студентами в сучасних умовах, бо вимагають нового підходу і нових стратегій для досягнення оптимальних результатів.

Відзначимо, що переваги медіатексту як навчального ресурсу до недавнього часу розглядалися науковцями дуже рідко, його використання в навчальному процесі було винятком. Уважаємо це неприйнятним, особливо з огляду на функціонування масмедійної сфери у сучасному інформаційному суспільстві. Так, робота з медіатекстами дасть змогу студентам бути поінформованими про сучасні світові події, бо не можна оминути той факт, що сучасна молодь нерідко виявляє певну необізнаність про стан подій у світі. 
Робота 3 медіатекстами дає можливість говорити про формування медіаграмотності особистості, що володіє культурою спілкування 3 медіа, творчими, комунікативними здібностями, критичним мисленням, уміннями повноцінного сприйняття, інтерпретації, аналізу та оцінки таких ресурсів. Окрім того, відзначимо поширеність, доступність, практичність і велику кількість різножанрових медіатекстів у сучасному цифровому освітньому середовищі. Увагу також звернено i на тематичне розмаїття медіатекстів, безліч матеріалів, присвячених актуальним подіям сьогодення: економіці, політиці, науці й освіті, культурі та спорту тощо. Усі ці проблеми становлять інтерес для студентів, заохочуючи ïх до іншомовної комунікації для обговорення запропонованих тем.

Медіатекст також має цінність як найбагатше джерело лінгвістичної інформації, бо саме в публіцистичному стилі можна знайти яскраву демонстрацію живої, актуальної англійської мови, саме в ньому проявляються всі активні в сучасній мові процеси на всіх її рівнях. Під час роботи 3 медіатекстами важливим $є$ опрацювання ключових слів, які називають найактуальніші для суспільства поняття, імена провідних політиків, відомих бізнесменів, діячів культури, спортсменів, тобто імена «героїв нашого часу», що відрізняються високою частотністю вживання саме в медіатекстах. Особливої уваги потребує мовна гра слів, що займає важливе місце в комунікативній стратегії сучасного медіадискурсу і представлена оказіональними словами та словосполученнями, каламбуром, метафорами, трансформаціями прецедентних текстів і фразеологізмів, графічними іграми тощо [3]. Зрозуміло, що подібна робота може викликати певні труднощі у студентів, що зумовлено низкою об'єктивних і суб'єктивних причин, до яких можна віднести невисокий рівень іншомовної лінгвістичної компетентності студентів, відсутність фонових знань (історичних, літературних, культурних тощо), навичок аналізувати, творчої роботи тощо.

Зазначимо, що багатий лінгвокультурний потенціал автентичних медіатекстів $є$ домінантною підставою для його використання на заняттях 3 англійської мови у 3ВО. 3 огляду на взаємодію мови, культури і свідомості, навчання іноземної мови має ставити за мету досягнення максимального взаємопорозуміння в міжкультурному діалозі, робити акцент не лише на лінгвістичних, а й на лінгвокультурологічних знаннях. Так, кожне заняття з іноземної мови - це перетин культур, практика міжкультурної комунікації, бо кожне іншомовне слово відображає світ і культуру народу, мова якого вивчається, за кожним словом знаходиться зумовлене національною сві- домістю уявлення про світ. Визначено, що через медіатекст відбувається реалізація інформативної функції масмедіа; певний формат інформаційного тексту; стійкі макро- і мікроструктури на рівні семантики; стійкі мовностилістичні ознаки; високий ступінь культуросвоєрідності; багаторазова відтворюваність тощо [1].

Аналіз різножанрових медіатекстів дає підстави стверджувати, що вони мають вагомий навчальний потенціал і сприяють заохоченню студентів до вивчення іноземної мови, бо являють собою цікавий мовний матеріал і привносять мотиваційний аспект в освітній процес [2, с. 120]. Це відбувається через те, що медіатексти сприймаються як джерело лінгвістичного і навчального матеріалу:

1) виконують одну 3 основних функцій як масової комунікації, так і мови: передачу актуальної багатоаспектної інформації, що є своєрідним маркером лінгвокультурологічних знань 3 урахуванням сталих і нових одиниць на рівні семантики і синтагматики;

2) характеризуються вживанням певних структурних типів словосполучень, наприклад дієслівних, що пов'язано з головним завданням тексту - повідомити про події, що відбуваються; поширеністю пасивних дієслівних конструкцій; великою кількістю лексичних з'єднань або складних слів, часто багатоелементних; цитуванням; специфічними текстоутворювальними елементами (фрази-зв'язки, посилання на джерела інформації, фрази для введення цитат);

3) містять значний обсяг ідіоматичних і тематичних словосполучень, що позначають реалії та артефакти конкретної країни і несуть інформацію про реальні персоналії, події та явища минулого i сьогодення;

4) мають певний формат - стійке співвідношення формальних ознак тексту і компонентів його змісту;

5) пронизані ідеологією того чи того народу, що відображає систему його цінностей і проявляється у певному ракурсі подачі та інтерпретації інформації (уявлення про події в інших країнах безпосередньо залежать від того, як різні ЗМІ інтерпретують певну подію навколишньої дійсності, а отже, під впливом медійного тексту відбувається формування інформаційної картини світу, яка тісно пов'язана з мовною картиною світу);

6) є високо культуроспецифічними ресурсами, бо представляють результат культурної іншомовної діяльності конкретного суспільства;

7) відзначаються системою синхронного й діахронного відтворення інформації (одну й ту саму тему можна висвітлити одночасно в різних 3МІ (газети, журнали, радіо, телебачення, мережа Інтернет тощо) 3 певною повторюваністю в часі) і можливістю аудіовізуального сприйняття тощо. 
Висновки. Отже, іншомовний медіатекст $є$ джерелом країнознавчих знань про найважливіші події та персоналії минулого і сучасності: у політиці, науці, мистецтві, спорті, архітектурі тощо. Медіатекст - це джерело широкого кола національно-культурних мовних одиниць, що становлять особливу цінність для вивчення іноземної мови в контексті міжкультурної взаємодії: фразеологізмів, прислів ”ів, національно-культурних стереотипів, ідіом, стилістичних фігур; звернення до прецедентних феноменів (прецедентні імена, події, ситуації, контексти) як одиниць когнітивної бази, що також сприяє взаєморозумінню під час міжкультурної комунікації. Медіатекст є важ- ливим засобом для вирішення широкого спектру комунікативних і власне мовних методичних завдань. Використання медіатекстів під час навчання іноземної мови майбутніх фахівців у виші сприяє заохоченню студентів до вивчення мови, бо такий медіаресурс являє собою цікавий мовний матеріал і привносить мотиваційний аспект в освітній процес, що відбувається через сприймання медіатексту як джерела лінгвістичного i навчального матеріалу.

У подальших розвідках заплановано дослідити систему відбору медіатекстів для їх подальшої інтерпретації, систему вправ для аудиторної та самостійної роботи з ними.

\section{ЛITЕРАТУРА}

1. Bell A. Approaches to Media Discourse. London, 2017. 304 p.

2. Lobachova I. Some Aspects of Forming Student Positive Motivation to Learn Foreign Languages. Пedaгогічні науки: теорія, історія, інноваиійні технологіï. 2019. № 5(89). С. 120-130. DOI 10.24139/ 2312-5993/2019.05/120-131

3. Teaching Media Text with the Key Concepts. URL: http://www.medienabc.org/page5/page40/page40. html.

4. Tony Fahy. What is a media text? Oxford Cambridge and RSA, 2015. URL: https://www.ocr.org.uk/blog/ what-is-a-media-text/.

5. Лобачова І.М. Автентичні тексти в навчанні англійської мови. Перспективні напрями сучасної науки та освіти : матеріали Всеукраїнської науково-практичної конференції. Слов'янськ, 2020. С. 94-97.

6. Українська мова : енциклопедія. Київ : Українська енциклопедія ім. М.П. Бажана, 2000. 752 с. URL: http://litopys.org.ua/ukrmova/um.htm.

\section{REFERENCES}

1. Bell, A. (2017). Approaches to Media Discourse. London, 304.

2. Lobachova, I. (2019). Some Aspects of Forming Student Positive Motivation to Learn Foreign Languages. Pedahohichni nauky: teoriia, istoriia, innovatsiini tekhnolohii. Sumy: Vyd-vo SumDPU im. A. S. Makarenka, 5 (89). 120-130. DOI 10.24139/2312-5993/2019.05/120-131

3. Teaching Media Text with the Key Concepts (1992). Available at: http://www.medienabc.org/page5/ page 40/page40.html

4. Tony, Fahy (2015). What is a media text? Oxford Cambridge and RSA. Available at: https://www.ocr.org.uk/ blog/what-is-a-media-text/

5. Lobachova, I.M. (2020). Avtentychni teksty v navchanni anhliiskoi movy [Authentic texts in the English language teaching]. Perspektyvni napriamy suchasnoi nauky ta osvity. Materialy Vseukrainskoi naukovo-praktychnoi konferentsii. Sloviansk, 94-97.

6. Ukrainska mova: Entsyklopediia [Ukrainian language: Encyclopedia]. Kyiv. Available at: http://litopys.org.ua/ukrmova/um.htm. 